\title{
High temperature pre-digestion of corn stover biomass for improved product yields
}

\author{
Roman Brunecky ${ }^{1 *}$, Sarah E Hobdey ${ }^{1}$, Larry E Taylor $\|^{1}$, Ling Tao², Melvin P Tucker ${ }^{2}$, Michael E Himmel ${ }^{1}$ \\ and Stephen R Decker ${ }^{1}$
}

\begin{abstract}
Introduction: The efficient conversion of lignocellulosic feedstocks remains a key step in the commercialization of biofuels. One of the barriers to cost-effective conversion of lignocellulosic biomass to sugars remains the enzymatic saccharification process step. Here, we describe a novel hybrid processing approach comprising enzymatic pre-digestion with newly characterized hyperthermophilic enzyme cocktails followed by conventional saccharification with commercial enzyme preparations. Dilute acid pretreated corn stover was subjected to this new procedure to test its efficacy. Thermal tolerant enzymes from Acidothermus cellulolyticus and Caldicellulosiruptor bescii were used to pre-digest pretreated biomass at elevated temperatures prior to saccharification by the commercial cellulase formulation.
\end{abstract}

Results: We report that pre-digestion of biomass with these enzymes at elevated temperatures prior to addition of the commercial cellulase formulation increased conversion rates and yields when compared to commercial cellulase formulation alone under low solids conditions.

Conclusion: Our results demonstrating improvements in rates and yields of conversion point the way forward for hybrid biomass conversion schemes utilizing catalytic amounts of hyperthermophilic enzymes.

Keywords: Biomass, Pretreatment, Enzymatic hydrolysis, CelA, E1, Caldicellulosiruptor bescii, Acidothermus cellulolyticus, Thermotoga maritima

\section{Background}

A key technical barrier to commercializing any biofuel (alcohol or hydrocarbon) or chemical from biomass via a sugar platform is the high cost and relative inefficiency of producing fermentable sugars from lignocellulosic biomass [1,2].

After thermochemical pretreatment of biomass, the resulting mixture must be cooled before commercial cellulases and/or conversion microbes are introduced. The current upper limit for commercial cellulases/hemicellulases is about $50^{\circ} \mathrm{C}$ (sequential hydrolysis and fermentation or SHF processes) and about $38^{\circ} \mathrm{C}$ for microbes (simultaneous saccharification and fermentation or SSF processes) [3-5]. Active cooling requires additional energy input and/ or cooling water, whereas passive cooling is relatively inexpensive, but requires time to be effective [6]. In the case of

\footnotetext{
* Correspondence: Roman.brunecky@nrel.gov

'Chemical Biosciences Center, National Renewable Energy Laboratory, 15013, Denver, West Parkway, Golden, CO 80401, USA

Full list of author information is available at the end of the article
}

thermophilic enzymes, we can take advantage of this inherent process cooling time in conjunction with the latent heat of mixing to "jump-start" the enzyme hydrolysis process, similar to high temperature gelatinization in starch hydrolysis. Employing a higher operating temperature hold step will enable thermophilic enzymes to be added earlier in the process, resulting in both time savings and improved conversion efficiency compared to using current mesophilic, commercial enzyme cocktails.

To evaluate this proposed process, we employed a 24-h, high temperature enzymatic pre-digestion step with a variety of thermophilic enzymes, followed by a conventional digestion step with a commercial enzyme cocktail. The thermophilic cellulases utilized in this case were a combination of known, thermal tolerant cellulases from Acidothermus cellulolyticus (E1 endoglucanase, $\mathrm{T}^{\mathrm{o}}{ }_{\mathrm{opt}}$ about $80^{\circ} \mathrm{C}$ ) and Caldicellulosirupter bescii (CelA, $\mathrm{T}^{\circ}{ }_{\mathrm{opt}}$ about $85^{\circ} \mathrm{C}$ ) [7-10]. Additional enzymes tested included a partially purified $C$. bescii culture broth containing predominantly CelA; as well as $C$. bescii xylanase enzymes and their 
fragments supplemented with a thermal tolerant $\beta$-Dglucosidase from Thermotoga maritima [11,12].

\section{Results and discussion}

\section{Low solids saccharification}

We initially used a high temperature enzyme loading of about $15 \%$ of the total enzyme loading to test the efficacy of the high temperature hold step at a low solids loading. The digestion conditions were $50 \mathrm{mM}$ sodium acetate buffer, pH 5.5 with $100 \mathrm{mM} \mathrm{NaCl}, 15 \mathrm{mM} \mathrm{CaCl}_{2}$ with the enzyme loadings listed below in each figure loaded on a milligrams per gram of glucan basis.

The high temperature hold digestion yielded approximately 10 to $15 \%$ higher glucan conversion at most time points observed (Figure 1). These results were subject to a one tailed homoscedastic T-test, and found to be significant ( $\mathrm{p}<0.05$ ). We also see that compared to the CTec2-only digestion, the high temp hold samples reach higher extents of conversion at earlier time points, this phenomenon is observed even if the CTec2 curve is shifted $24 \mathrm{~h}$ earlier

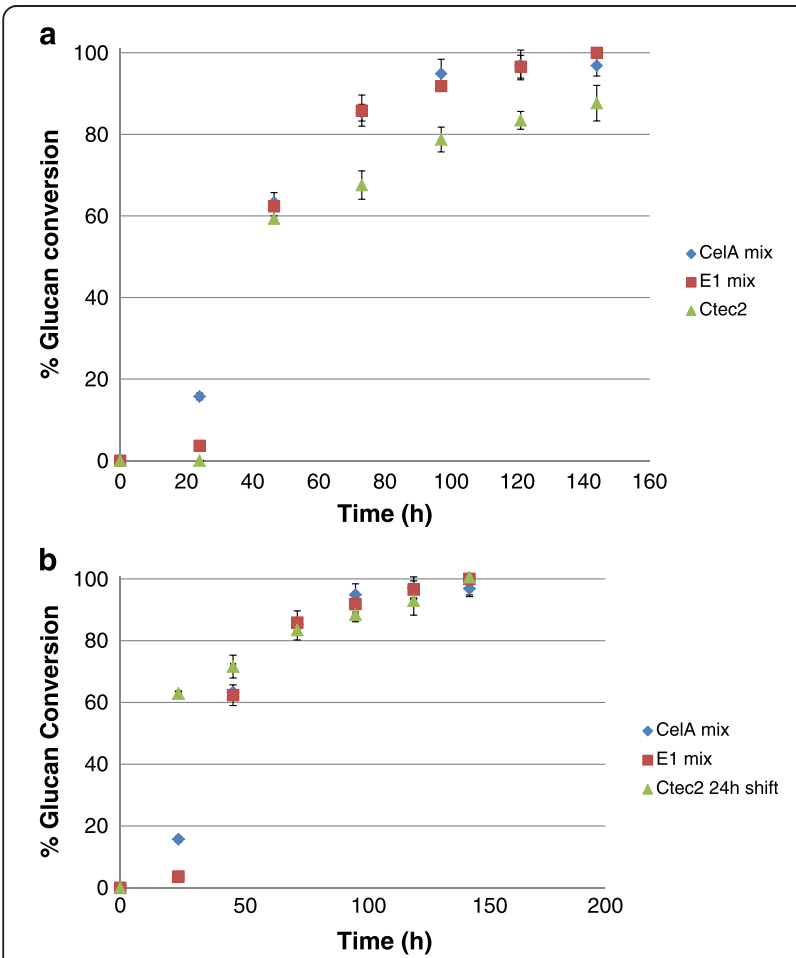

Figure 1 Comparison of biomass conversion with and without a high temperature hold step. a: Initial high temperature hold experiment. CelA mix: $3 \mathrm{mg}$ CelA/g glucan, $1 \mathrm{mg} \mathrm{E1/g}$ glucan, 0.5 mg $\beta$-D-glucosidase/g glucan, and 16 mg CTec2/g glucan. E1 mix: 3 $\mathrm{mg} \mathrm{E1/g}$ glucan and $17 \mathrm{mg}$ CTec2/g glucan. CTec2: $20 \mathrm{mg} \mathrm{CTec2/g}$ glucan. b: Initial high temperature hold experiment with $\mathrm{CTec} 2$ shifted 24 h. CelA mix: 3 mg CelA/g glucan, 1 mg E1/g glucan, 0.5 mg $\beta$-D-glucosidase/g glucan, and 16 mg CTec2/g glucan. E1 mix: 3 $\mathrm{mg} \mathrm{E1/g}$ glucan and $17 \mathrm{mg} \mathrm{CTec2/g} \mathrm{glucan.} \mathrm{CTec2:} 20 \mathrm{mg}$ $\mathrm{CTec} 2 / \mathrm{g}$ glucan. (i.e., same start time), although the improvements in conversion are smaller (Figure $1 \mathrm{~b}$ ).

\section{Enzyme loading optimization}

To optimize the thermophilic enzyme loadings, we assayed high, mid-range, and low thermophilic enzyme loadings for the high temperature hold, while maintaining the total enzyme loading at $20 \mathrm{mg} / \mathrm{g}$ glucan. Optimization of conditions for the high temperature hold indicate that higher loadings of the thermophilic enzymes containing CelA provide stronger initial boosts to the glucan conversion $(24 \mathrm{~h}$ ) (Figure $2 \mathrm{a}$ ) and also provide subsequent 4 to $7 \%$ enhancements in conversion when comparing the best CelA digestions to CTec2 digestions (Figures $2 \mathrm{a}$ and $2 \mathrm{~b}$ ). These results were subject to a one-tailed homoscedastic $t$-test, and found to be significant $(P<0.05)$ for the CelA low and E1 mid

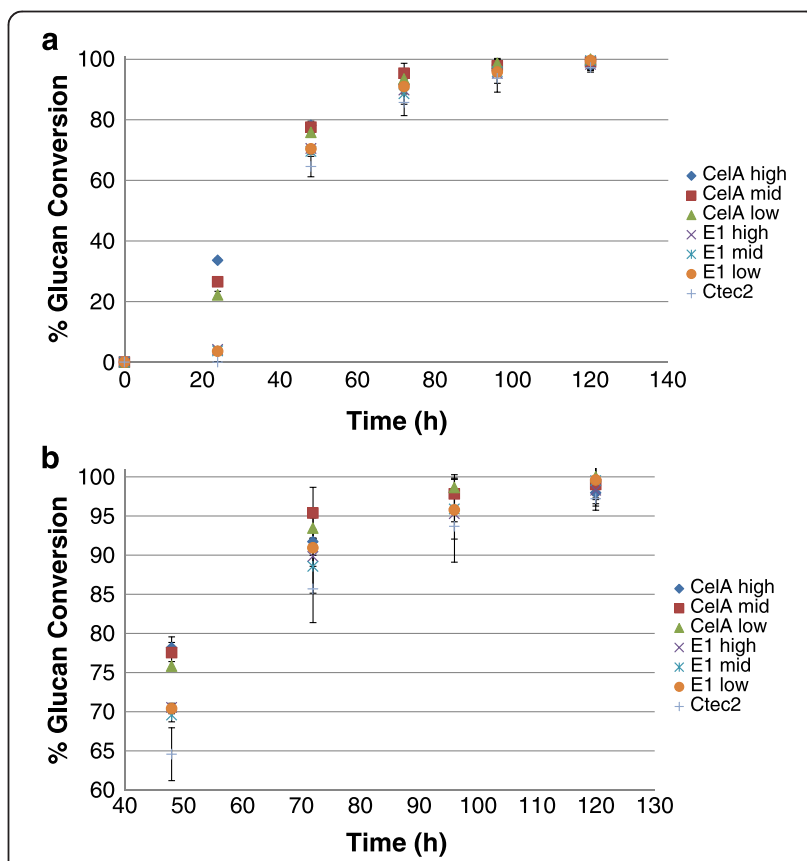

Figure 2 Opimization of the high temp hold step. a: High temperature hold optimization. The digestion conditions are $50 \mathrm{mM}$ acetate buffer, pH 5.5 with $100 \mathrm{mM} \mathrm{NaCl}, 15 \mathrm{mM} \mathrm{CaCl}_{2}$ with enzyme loadings listed below. * Denotes a statistically $(P<.05)$ relevant improvement in conversion compared to CTec2 at $120 \mathrm{~h}$. High CelA mix: $5 \mathrm{mg} \mathrm{C}$. bescii broth/g glucan, $1 \mathrm{mg} \mathrm{E1/g}$ glucan, $0.5 \mathrm{mg}$ $\beta$-glucosidase/g glucan, and $13.5 \mathrm{mg}$ CTec2/g glucan. Mid CelA mix: $3 \mathrm{mg} \mathrm{C.} \mathrm{bescii} \mathrm{broth/g} \mathrm{glucan,} 1 \mathrm{mg} \mathrm{E1/g}$ glucan, $0.5 \mathrm{mg}$ $\beta$-glucosidase/g glucan, and $15.5 \mathrm{mg} \mathrm{CTec} / \mathrm{g}$ glucan. Low CelA mix:* $2 \mathrm{mg} \mathrm{C}$. bescii broth/g glucan, $1 \mathrm{mg} \mathrm{E1/g}$ glucan, $0.5 \mathrm{mg}$ $\beta$-glucosidase/g glucan, and $16.5 \mathrm{mg} C \mathrm{CTec} 2 / \mathrm{g}$ glucan. Low E1 mix: $3 \mathrm{mg} \mathrm{E1/g}$ glucan, $0.5 \mathrm{mg} \beta$-glucosidase/g glucan, and $16.5 \mathrm{mg} \mathrm{CTec} / \mathrm{g}$ glucan. Mid E1 mix:* $4 \mathrm{mg} \mathrm{E1/g} \mathrm{glucan,} 0.5 \mathrm{mg}$ $\beta$-glucosidase/g glucan, and $15.5 \mathrm{mg} C \mathrm{CTec} 2 / \mathrm{g}$ glucan. High E1 mix: 6 mg E1/g glucan, 0.5 mg $\beta$-glucosidase/g glucan, and $13.5 \mathrm{mg}$ CTec2/g glucan. CTec2: 20 mg CTec2/g glucan. b: High temperature hold optimization close-up of $48 \mathrm{~h}+$ digestion points to better illustrate differences. 
loadings at $120 \mathrm{~h}$. This improvement is still observable for the other high temperature hold enzymes, but the extents of conversion are slightly lower and not statistically significant at $120 \mathrm{~h}$. This result may be due, in part, to the plateau effect that occurs toward the latter extent of conversion time points; however, if one examines the data on a time-to-target basis, the high temperature hold provides clear benefits, achieving equivalent extents of conversion $24 \mathrm{~h}$ or more prior to the CTec- 2 control conversion curve. This $20 \%$ reduction in processing time will improve the economics of large-scale biomass conversion processes. Also noteworthy is the determination that xylan conversion displays a similar, although slightly less dramatic, effect in conversion extents, achieving a $10 \%$ improvement at early time points and approximately 3 to $4 \%$ at the digestion endpoint. These data are statistically significant $(P<0.05)$ for all CelA loadings at $96 \mathrm{~h}$, and significant only for the CelA high loading at $120 \mathrm{~h}$ (Figure 3).

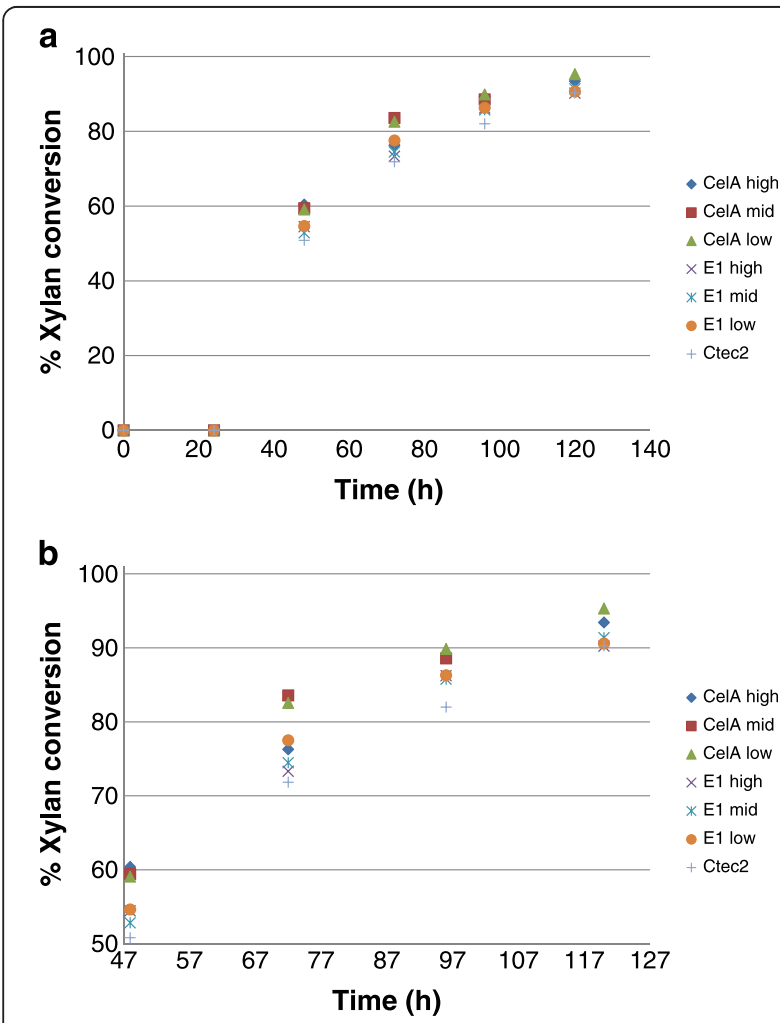

Figure 3 Xylan conversion. The digestion conditions as described in Figure $2 \mathbf{a}$. We note here that while all CelA loadings are statistically significantly better than the control at the 96-h mark, only the CelA high loading showed a statistically $(P<.05)$ relevant improvement in conversion compared to CTec2 at $120 \mathrm{~h}$. b: High temperature hold optimization close-up of $48 \mathrm{~h}+$ xylan digestion points to better illustrate differences.

\section{High solids stepwise saccharification at higher enzyme loading}

To validate our low solids loading results, we ran the high temperature hold experiments on a limited scale using $20 \%$ solids loading conditions. The total enzyme loadings were $40 \mathrm{mg} \mathrm{CTec} 2 / \mathrm{g}$ glucan or $36 \mathrm{mg} \mathrm{CTec} 2 / \mathrm{g}$ glucan and $4 \mathrm{mg} \mathrm{E1/g}$ glucan. The results are reported in Figure 4. Our results show that a stepwise digestion with E1 increases the glucan-to-glucose conversion by approximately $10 \%$ on washed solids pretreated corn stover (PCS) compared to samples that were pre-incubated without E1 (Figure 4). This is especially significant, considering that samples containing E1 permitted a 10\% lower CTec2 loading. These results are consistent with those results obtained in the low solids loading cases.

\section{Techno-economic analysis}

Minimum ethanol selling price (MESP) values were estimated using our results from the initial high temperature hold experiment (Figure 2). These MESP results are summarized in Table 1 . The MESP decreased steadily as the enzymatic hydrolysis time was increased; a result we feel is mainly due to an increasing yield of monomer glucose. Experimental data were taken every day to verify enzymatic hydrolysis yield, or monomer glucose yield. Initially, the CelA mix showed a lower initial yield compared to CTec2 (4 d) alone; however, starting at day 4, we see an improvement in the yield results. We have included a hypothetical comparison with CTec2 showing the effect of starting the digestion at the same time as the predigestion with CTec2 $(5 \mathrm{~d})$, which assumes an instant cooling scenario, where the CTec 2 enzyme can be added immediately. We can see from these studies that there is a benefit of 14 to 18 cents per gallon of ethanol produced from utilizing the high temperature hold step for the best case of the CelA-containing mix compared to the CTec2 digestions, depending upon whether or not there is a 24-h delay in starting the CTec2 digestion as the biomass cools.

\section{Conclusions}

A high temperature hold step utilizing thermophilic or hyperthermophilic enzymes shows promise in a biomass conversion process where gradual cooling (dilution/ neutralization cooling only or air cooling) of biomass is utilized. We observe approximately 10 to $15 \%$ improvements in conversion at given time points compared to CTec2 digestion alone in these specific cases. In a process scenario where biomass cooling is rapid, such as when active cooling is utilized, the gains are less impressive, perhaps a $5 \%$ improvement at best. However, endpoint conversions are still typically a few percent higher compared to the mesophilic CTec2 cocktail alone. This may be in part due to possible synergistic mechanisms 


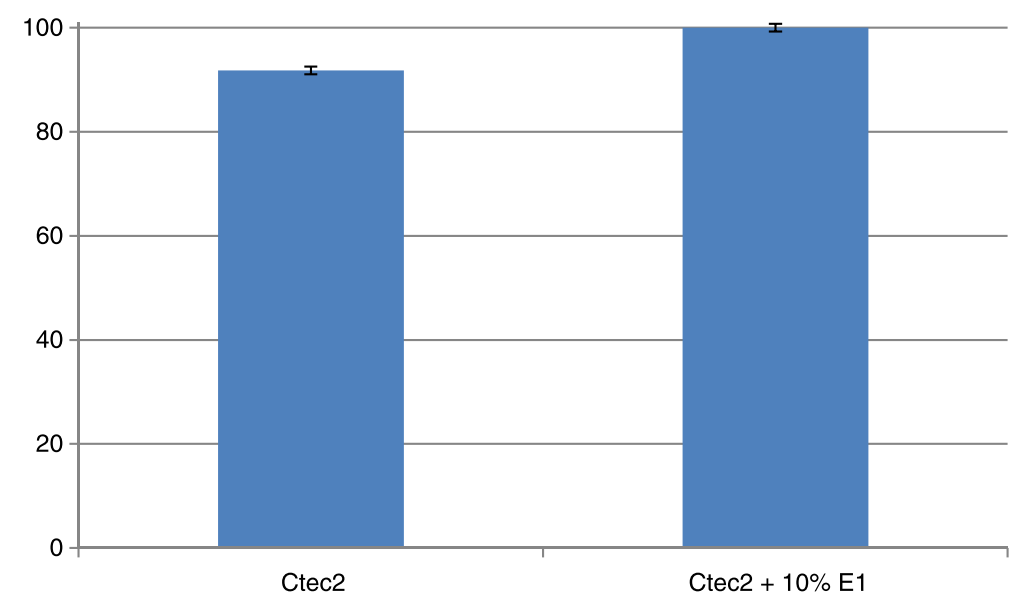

Figure 4 20\% High solids validation test. CTec2 loaded at 40 mg/g biomass. CTec2 + E1 loaded at 4 mg/g biomass E1 and 36 mg/g CTec2.

between the novel mechanism of the CelA-based cocktail, which creates cavities within the biomass, and the more conventional surface ablation hydrolysis model displayed by fungal enzymes [7]. However, the E1-only cocktail demonstrates almost an identical improvement, and the mechanism of E1, an endoglucanase, is likely to be primarily increasing the number of reducing ends available for the cellobiohydrolases in subsequent fungal cocktail digestion. We suggest that these enzymes exhibit different modes of synergy with the commercial fungal enzyme cocktail. Our proposed high temperature hold process may be in some ways compared to the industrial application of thermophilic $\alpha$-amylases utilized in the modern dry grind process for corn starch-derived ethanol. In that process, addition of hyperthermophilic $\alpha$-amylases (Takatherm ${ }^{\circ}$ ) to the corn mash immediately following cooking in the hydroheaters has dramatically improved conversion rates for soluble sugar production. However, given the major differences between the two feedstocks, especially that of the insolubility of lignocellulose, we expect less dramatic improvements for our process compared to starch liquefaction and conversion.

We have determined that low loadings of the high temperature cellulose cocktails can provide better improvements in both rates of digestion and final glucan conversion extents compared to CTec2 alone. The proposed improvements from this study have been validated for both low solids conditions and at endpoint conversion

Table 1 Minimum ethanol selling price

\begin{tabular}{llll}
\hline MESP $\mathbf{( \$ / g a l )}$ & & & \\
\hline & 3 day & 4 day & $\mathbf{5 ~ d a y}$ \\
\hline CelA mix & $\$ 2.50$ & $\$ 2.22$ & $\$ 2.12$ \\
E1 mix & $\$ 2.52$ & $\$ 2.21$ & $\$ 2.15$ \\
CTec2 5 d & $\$ 2.44$ & $\$ 2.30$ & $\$ 2.26$ \\
CTec2 4 d & nd & $\$ 2.44$ & $\$ 2.30$ \\
\hline
\end{tabular}

conditions for high solids. Techno-economic analysis using our results suggests that a significant savings is achievable due to the reduced processing times and improved extents of conversion. If the results can be validated on a large scale, they should provide a roadmap to improved conversion yields and reduced processing times for current biomass saccharification schemes, and will be drop-in compatible with existing plant configurations.

\section{Materials and methods}

\section{Biomass for high and low solids digestions}

Pretreated biomass was obtained from the 2012 state of technology production run in the NREL Integrated BioRefinery Facility (IBRF) pilot plant. Briefly, Pioneer 33B51 tub ground corn stover was received in 2003 from Wray, CO (Kramer Farm) and was further knife milled (Jordan Reduction Systems) through a 3/4-inch rejection screen in the NREL IBRF. Corn stover deacetylation and sulfuric acid impregnation was performed in the 1900-L Dynamic Impregnator (DI) tank (American Process Systems, Gurnee, IL). Dry corn stover was added to the tank along with a dilute sodium hydroxide solution $(0.4 \mathrm{w} / \mathrm{w})$ to deacetylate the material prior to pretreatment. The material was dewatered, neutralized, acid impregnated, and pretreated. The pretreatment conditions utilized were $160^{\circ} \mathrm{C}, 0.8 \%(\mathrm{w} / \mathrm{w}) \mathrm{H}_{2} \mathrm{SO}_{4}$, and 10 $\mathrm{min}$ in a large horizontal pretreatment reactor (Mesto Inc., Norcross, GA) configured for two-tube operation (Pretreatment ID P120927) [13]. The biomass was washed with water by centrifugation until a $\mathrm{pH}$ of 5 was observed. The biomass composition was analyzed as previously described and is listed in Table 2 [14].

\section{Biomass for high solids digestions}

Corn stover biomass was prepared and pretreated as follows: Pioneer maize variety 33A14 whole stover from 
Table 2 Composition analysis of process relevant biomass

\begin{tabular}{|c|c|c|c|c|c|c|c|c|c|c|c|c|}
\hline Sample ID & $\begin{array}{c}\% \\
\text { Ash }\end{array}$ & $\begin{array}{c}\% \\
\text { Protein }\end{array}$ & $\begin{array}{c}\% \\
\text { Lignin }\end{array}$ & $\begin{array}{c}\text { Lignin } \\
\text { corrected? }\end{array}$ & $\begin{array}{c}\% \\
\text { Glucan }\end{array}$ & $\begin{array}{c}\% \\
\text { Xylan }\end{array}$ & $\begin{array}{c}\% \\
\text { Galactan }\end{array}$ & $\begin{array}{c}\% \\
\text { Arabinan }\end{array}$ & $\begin{array}{c}\% \\
\text { Fructan }\end{array}$ & $\begin{array}{c}\% \\
\text { Uronic acid }\end{array}$ & $\begin{array}{c}\% \\
\text { Acetate }\end{array}$ & $\begin{array}{c}\text { Total } \\
\%\end{array}$ \\
\hline $\begin{array}{l}\text { P120927 DCS (high and } \\
\text { low solids) }\end{array}$ & 4.07 & ND & 23.9 & No & 63.9 & 5.0 & 0.6 & 0.8 & 0.00 & ND & 0.2 & 98.5 \\
\hline XT110613 A (high solids) & 5.12 & ND & 26.8 & No & 60.2 & 2.9 & 0 & 0.9 & 0.2 & ND & 0.4 & 96.6 \\
\hline
\end{tabular}

the Kramer Farm in Wray, CO was pretreated in the 200-kg/day continuous, high-solids, pilot-scale horizontal pretreatment reactor system at NREL using $2 \%$ sulfuric acid at $158^{\circ} \mathrm{C}$ with a residence time of $5 \mathrm{~min}$ (Pretreatment ID XT110613). Deacetylation of the stover was performed using $0.1 \mathrm{M} \mathrm{NaOH}$ at an $8 \%$ solids loading at $80^{\circ} \mathrm{C}$, and mixed at $15 \mathrm{rpm}$ for $2 \mathrm{~h}$ prior to diluteacid pretreatment. The "washed PCS" was washed with water by centrifugation until a $\mathrm{pH}$ of 5 was observed. The washed PCS was air-dried on the bench top with manual mixing in order to achieve up to $20 \%$ solids in the final reaction vessel (after the addition of enzyme solutions and buffer). The biomass was analyzed as previously described [14].

\section{Enzymes}

The enzyme mixtures utilized for the high temperature hold were selected for their abilities to operate at high temperature regimes, and the hyperthermophilic enzymes and mixtures were selected for their ability to operate at $80^{\circ} \mathrm{C}$. For the hyperthermophilic conditions, we utilized mixtures of the following enzymes: the multifunctional (endocellulase, exocellulase, xylanase) CelA was from $C$. bescii [7]. CelA was supplemented with the endocellulase E1 from A. cellulolyticus [8], and the $\beta$-D-glucosidase from T. maritima was obtained from Megazyme International Ireland (Bray, Ireland). We also utilized a CelA-enriched fraction of culture broth from cellulose-grown $C$. bescii, which is composed primarily of CelA, for some experiments. These enzyme mixtures were then supplemented with twice desalted Cellic ${ }^{\oplus}$ CTec2 from Novozymes (Bagsvaerd, Denmark) after the initial 24$\mathrm{h}$ high temperature hold step. Details of each mixture are included in each figure.

\section{Time course saccharification - low solids}

Stepwise saccharifications at about $2 \%$ solids loading were performed in a $1.5-\mathrm{mL}$ volume in two steps: 1) high temperature $\left(80^{\circ} \mathrm{C}\right)$ digestion using a mixture of thermophilic enzymes and 2) a lower temperature digestion $\left(50^{\circ} \mathrm{C}\right)$ using the enzyme cocktail Cellic ${ }^{\oplus} \mathrm{CTec} 2$. All enzyme loadings were loaded on a mass basis, that is, milligrams of enzyme per gram of biomass, with a final total loading of $20 \mathrm{mg} / \mathrm{g}$. Samples were taken generally at 24-h intervals, and the enzymes were inactivated by boiling for 15 min. Samples were filtered through $0.45 \mu \mathrm{m}$ Acrodisc syringe filters and analyzed for glucose, and cellobiose by
HPLC. Samples of $20 \mu \mathrm{L}$ were injected onto an Agilent 1100 HPLC system equipped with a BioRad Aminex HPX-87H $300 \mathrm{~mm} \times 7.8 \mathrm{~mm}$ column heated to $55^{\circ} \mathrm{C}$. A constant flow of $0.6 \mathrm{~mL} / \mathrm{min}$ was used with $0.1 \mathrm{M} \mathrm{H}_{2} \mathrm{SO}_{4}$ in water as the mobile phase to give optimal sugar separation. Glucose, xylose, and cellobiose were quantified against independent standard curves. All experiments were performed in triplicate, and the resulting extents of conversion are shown as a percentage of maximum theoretical glucan converted. Measurements were standardized to a maximum conversion of $100 \%$, and thus, the results between Figures 1 and 2 should not be compared directly. We have also performed a one-tailed homoscedastic $t$-test on all data and reported the results as relevant in the paper.

\section{High solids endpoint saccharification}

The initial high solids experiment was an endpoint saccharification performed in two steps: 1) high temperature digestion using purified endocellulase E1 from A. cellulolyticus followed by 2) a lower temperature digestion using the enzyme cocktail, Cellic ${ }^{\circledR}$ CTec2. Two-step saccharifications were performed on washed PCS (XT110613-Kramer 33A14, Table 2).

Digestions were carried out in $20-\mathrm{mL}$ glass scintillation vials loaded to an equal final weight of $3.2 \mathrm{~g}$ biomass to maintain similar mixing characteristics. Biomass was dispensed by hand and weighed to the nearest 0.001 g. Digestions of PCS were carried out on $20 \%$ solids in a two-step format. In step 1, four $\mathrm{mg} / \mathrm{g}$ glucan of purified E1 was added to the samples and incubated with shaking $(100 \mathrm{rpm})$ at $70^{\circ} \mathrm{C}$ for $24 \mathrm{~h}$. After $24 \mathrm{~h}$, the temperature was lowered to $45^{\circ} \mathrm{C}$ for $2 \mathrm{~h}$ to allow the sample temperature to equilibrate. In step 2, following equilibration at $45^{\circ} \mathrm{C}, \mathrm{CTec} 2$ was added to a final enzyme concentration of $40 \mathrm{mg} / \mathrm{g}$ glucan and incubated for $96 \mathrm{~h}$, with shaking $(100 \mathrm{rpm})$ at $40^{\circ} \mathrm{C}$. Endpoint samples were taken at $120 \mathrm{~h}$ and frozen at $-20^{\circ} \mathrm{C}$ to stop the hydrolysis until all incubations were complete. The samples were then boiled for $10 \mathrm{~min}$ to denature the enzymes and diluted to $12.0 \mathrm{~mL}$ with Nanopure $\mathrm{H}_{2} \mathrm{O}$ and filtered through $0.45 \mu \mathrm{m}$ nylon Acrodiscs. Carbohydrate quantification was performed for five monomeric sugars (glucose, xylose, galactose, arabinose, and fructose), cellobiose, and "total oligomeric carbohydrates" using an Agilent 1100 HPLC system with a Shodex sugar SP0810 analytical column with refractive index detection. The calibration curves had 
eight points with a range of 0.04 to $35 \mathrm{~g} / \mathrm{L}$ with a validation sample at $1.5 \mathrm{~g} / \mathrm{L}$. All components were present in the calibration standards at equal levels except for the "total oligomeric carbohydrates," which were estimated by applying the response factor for cellobiose to all peak areas that eluted prior to glucose and includes cellobiose.

\section{Techno-economic analysis}

Process economics analysis includes a conceptual level of process design to develop a detailed process flow diagram (based on research data), rigorous materials and energy balance calculations (via commercial simulation tools, Aspen Plus), capital and operational cost estimation (capital expenditures, CAPEX, and operating expenses, OPEX, via an in-house model using spreadsheets), a discounted cash flow economic model, and the calculation of a minimum ethanol selling price (MESP). Rigorous material and energy balance calculations are performed to quantify unit-level cost estimates. For a given set of conversion parameters, material and energy balance and flow rate information are generated using Aspen Plus process simulation software (Aspen Plus. Release 7.2, Aspen Technology Inc., Cambridge MA), assuming a defined feed rate to the biorefinery of 2,205 dry US tons of corn stover per day (2,000 metric tonnes per day). These data are used to size and cost process equipment to calculate capital expense (CAPEX) and to calculate raw material and other operating costs (OPEX).

The most recent NREL design report model has been used as the baseline for modeling the variation of enzymatic hydrolysis yields in this study [13]. The integrated process model starts from dilute acid pretreatment at a moderate to high temperature $\left(150\right.$ to $\left.190^{\circ} \mathrm{C}\right)$ for a short time followed by enzymatic hydrolysis and co-fermentation with recombinant Zymomonas mobilis. Cellulase enzyme made onsite is added to the hydrolysate at an optimized temperature for enzyme activity. The monomeric xylose from the NREL FY2012 pilot demonstration reaches over $50 \mathrm{~g} / \mathrm{L}$ and monomeric glucose reaches $100 \mathrm{~g} / \mathrm{L}$ after enzymatic hydrolysis [13]. If saccharification and fermentation steps are conducted at different temperatures, a cooling step is required to ensure growth of fermenting organism Zymomonas mobilis at anaerobic conditions. Five days are required to convert most of the cellulose and xylose to the beer liquor with $>70 \mathrm{~g} / \mathrm{L}$ of ethanol which is then sent to recovery and purification, which uses standard adsorption technology. The solids after fermentation are separated and combusted in a fluidized bed combustor to produce high pressure steam for electricity credits and process heat. Detailed techno-economic analysis development can be found in NREL FY2012 state of technology report as well as previous NREL design reports $[15,16]$. In this work, process conditions and yields are updated only to the enzymatic hydrolysis area while maintaining process modeling of the other areas, to incorporate the higher temperature enzymatic pre-digestion step with hyperthermophilic enzymes coupled to a subsequent conventional saccharification. The MESPs are then calculated based on the experimental data.

\section{Abbreviations}

CAPEX: capital expenditures; IBRF: Integrated BioRefinery Facility; MESP: minimum ethanol selling price; OPEX: operating expenses; PCS: pretreated corn stover; SHF: sequential hydrolysis and fermentation; SSF: simultaneous saccharification and fermentation.

\section{Competing interests}

Financial: Roman Brunecky and Michael E. Himmel have a patent pertaining to the use of CelA, though not for this specific use, US2014/0017735A1. Non-Financial: There are no non-financial competing interests.

\section{Authors' contributions}

All authors read and approved the final version of the manuscript. RB carried out low solids experiments and performed data analysis, provided CelA mix used in the study, and wrote the manuscript. SEH carried out high solids experiments and performed data analysis. LET purified E1 enzyme for use in the study and helped with data analysis. LT carried out the techno-economic analysis based on experiments performed by RB. MPT prepared and provided the pretreated biomass used in the study. MEH helped with the preparation and revision of the manuscript and conceived of the study. SRD helped with preparation and revision of the manuscript.

\section{Acknowledgments}

This work was supported by the US Department of Energy under Contract No. DE-AC36-08GO28308. Funding for the work was provided by the DOE Office of Energy Efficiency and Renewable Energy, Bioenergy Technologies Office.

\section{Author details}

${ }^{1}$ Chemical Biosciences Center, National Renewable Energy Laboratory, 15013, Denver, West Parkway, Golden, CO 80401, USA. ²National Bioenergy Center, National Renewable Energy Laboratory, 15013, Denver, West Parkway, Golden, CO 80401, USA.

Received: 26 August 2014 Accepted: 14 November 2014 Published online: 03 December 2014

\section{References}

1. Aden A, Foust T: Technoeconomic analysis of the dilute sulfuric acid and enzymatic hydrolysis process for the conversion of corn stover to ethanol. Cellulose 2009, 16(4):535-545.

2. Klein-Marcuschamer D, Oleskowicz-Popiel P, Simmons BA, Blanch HW: The challenge of enzyme cost in the production of lignocellulosic biofuels. Biotechnol Bioeng 2012, 109(4):1083-1087.

3. Drissen RET, Maas RHW, Tramper J, Beeftink HH: Modelling ethanol production from cellulose: separate hydrolysis and fermentation versus simultaneous saccharification and fermentation. Biocatal Biotransformation 2009, 27(1):27-35

4. Olofsson $\mathrm{K}$, Bertilsson M, Liden G: A short review on SSF - an interesting process option for ethanol production from lignocellulosic feedstocks. Biotechnol Biofuels 2008, 1(1):7.

5. $\mathrm{Xu}$ Z, Huang F: Pretreatment methods for bioethanol production. Appl Biochem Biotechnol 2014, 1-20.

6. Alfani F, Gallifuoco A, Saporosi A, Spera A, Cantarella M: Comparison of SHF and SSF processes for the bioconversion of steam-exploded wheat straw. J Ind Microbiol Biotechnol 2000, 25(4):184-192.

7. Brunecky R, Alahuhta M, Xu Q, Donohoe BS, Crowley MF, Kataeva IA, Yang SJ, Resch MG, Adams MWW, Lunin W, Himmel ME, Bomble YJ: Revealing nature's cellulase diversity: the digestion mechanism of Caldicellulosiruptor bescii CelA. Science 2013, 342(6165):1513-1516.

8. Baker JO, Adney WS, Nleves RA, Thomas SR, Wilson DB, Himmel ME: A new thermostable endoglucanase, Acidothermus cellulolyticus E1. Appl Biochem Biotechnol 1994, 45-46(1):245-256. 
9. Zverlov V, Mahr S, Riedel K, Bronnenmeier K: Properties and gene structure of a bifunctional cellulolytic enzyme (CelA) from the extreme thermophile 'Anaerocellum thermophilum' with separate glycosyl hydrolase family 9 and 48 catalytic domains. Microbiology-UK 1998, 144:457-465.

10. Sakon J, Adney WS, Himmel ME, Thomas SR, Karplus PA: Crystal structure of thermostable family 5 endocellulase E1 from Acidothermus cellulolyticus in complex with cellotetraose. Biochemistry 1996, 35(33):10648-10660.

11. Gabelsberger J, Liebl W, Schleifer K-H: Purification and properties of recombinant $\beta$-glucosidase of the hyperthermophilic bacterium Thermotoga maritima. Appl Microbiol Biotechnol 1993, 40(1):44-52.

12. Park T-H, Choi K-W, Park C-S, Lee S-B, Kang H-Y, Shon K-J, Park J-S, Cha J:

Substrate specificity and transglycosylation catalyzed by a thermostable $\beta$-glucosidase from marine hyperthermophile Thermotoga neapolitana. Appl Microbiol Biotechnol 2005, 69(4):411-422.

13. Tao L, Schell D, Davis R, Tan E, Elander R, Bratis A: NREL 2012 Achievement of Ethanol Cost Targets: Biochemical Ethanol Fermentation via Dilute-Acid Pretreatment and Enzymatic Hydrolysis of Corn Stover. NREL 2014. [http://www.nrel.gov/docs/fy14osti/61563.pdf]

14. Sluiter A: LAP - Determination of Structural Carbohydrates and Lignin in Biomass. 2006:9572.

15. Aden A: Lignocellulosic Biomass to Ethanol Process Design and Economics Utilizing Co-Current Dilute Acid Prehydrolysis and Enzymatic Hydrolysis for Corn Stover. In Other Information: PBD: 1 Jun 20022002. 154. p. Medium: ED; Size.

16. Humbird D: Process Design and Economics for Biochemical Conversion of Lignocellulosic Biomass to Ethanol: Dilute-Acid Pretreatment and Enzymatic Hydrolysis of Corn Stover; 2011.

doi:10.1186/s13068-014-0170-2

Cite this article as: Brunecky et al:: High temperature pre-digestion of corn stover biomass for improved product yields. Biotechnology for Biofuels 2014 7:170.

\section{Submit your next manuscript to BioMed Central and take full advantage of:}

- Convenient online submission

- Thorough peer review

- No space constraints or color figure charges

- Immediate publication on acceptance

- Inclusion in PubMed, CAS, Scopus and Google Scholar

- Research which is freely available for redistribution 